\title{
The use of green mussel as bioindicator of heavy metal pollution in Indonesia: a review
}

\author{
Ismail Saleh, Syamsir Syamsir* (i), Vita Pramaningsih ${ }^{\circledR}$, Hansen Hansen \\ ${ }^{1}$ Department of Environmental Health, Universitas Muhammadiyah Kalimantan Timur, Samarinda, Indonesia \\ *Correspondence: sya809@umkt.ac.id
}

Received: June 2, 2021 Accepted: November 2, 2021

\begin{abstract}
Asian green mussel is a marine animal that is used as food by most Indonesians. The mussels are widely cultivated in tropical countries such as Indonesia, Malaysia, Thailand, and other Asian countries. The mussel, known as perna viridis, is marine biota that is a filter feeder in the waters. Therefore, the quality of its meat is greatly influenced by the quality of the sea in its habitat. It is a food that is quite popular with the community but can endanger public health due to the accumulation of heavy metals. This study used a literature review by collecting data related to heavy metal concentrations in green mussel tissue in Indonesia. The results showed that the mussels from several sampling locations still exceeded the maximum acceptable limits of lead $(\mathrm{Pb})$, mercury $(\mathrm{Hg})$, and cadmium $(\mathrm{Cd})$ concentration according to the standards of the food and drug administration of the Republic of Indonesia. Consumption of green mussels can increase health risks if you frequently consume them from cultivating or catching locations that have been contaminated with heavy metals.
\end{abstract}

Keywords: Green mussel, Perna viridis, Bioindicator, Health risk, Heavy metal

\section{Introduction}

Asian green mussel is a marine animal that is used as food by most Indonesians. Cultivation of green mussels is found in various coastal areas of Indonesia. The high public interest in consuming the mussel makes it a salable commodity in the market. According to data from the central statistics agency in a report from the ministry of trade of the Republic of Indonesia, shellfish is one of the most commonly purchased types of food for consumption by people [1]. The culture of the Indonesian people who like seafood is also a factor in the high consumption of green mussels in this archipelago [2,3]. Green mussels are widely cultivated in tropical countries such as Indonesia, Malaysia, Thailand, and other Asian countries [4-7]. The cultivation is not influenced by the season so that it can be productive all year round [8]. The mussels can live in a variety of aquatic environmental conditions so that they are easier to cultivate. However, green mussels can accumulate water pollutants so that they can present health risks if consumed [9].

Asian green mussel, known as Perna viridis, is marine biota that is a filter feeder in the waters. Therefore, the quality of its meat is greatly influenced by the quality of the sea in its habitat. The green mussel tissue can accumulate various pollutants from the sea. The disposal of industrial waste in the sea can affect the increasing accumulation of heavy metals in the tissue. The ability to accumulate pollutants in water so is often used as a bioindicator of seawater quality. The accumulation of heavy metals in the green mussel tissue indicates heavy metal pollution in the sea [10]. Cultivation of seashells must ensure that the concentration of heavy metals in the waters has met the standards. For example, green mussels found in Jakarta Bay's cultivation location show lead (Pb) concentrations of 0.202-0.289 mg/kg [11]. The concentration is still categorized as safe. If $\mathrm{Pb}$ exposure occurs continuously, it can increase the accumulation of $\mathrm{Pb}$ in green mussels.

The accumulation of heavy metals in green mussels is found in several marine areas in Southeast Asia. A total of $2.28 \mu \mathrm{g} \mathrm{g}^{-1} \mathrm{~Pb}$ and $8.96 \mu \mathrm{g} \mathrm{g}^{-1}$ copper $(\mathrm{Cu})$ were found in green mussels in Johor, Malaysia [12]. Heavy metals have also been detected in green mussels off the coast of Singapore [13]. Heavy metals in green mussel tissue are also found in the West Pacific region [14]. The accumulation of heavy metals in the tissue can endanger human health if consumed for a long time. Moreover, heavy metals are non-essential to the human body, so they can be carcinogenic if they enter the body [10,15]. Industrial activities in coastal areas can endanger marine life. That can happen if the industry dumps waste that does not meet quality standards into the sea. The location of green mussel cultivation around the industry can increase the concentration of heavy metals in the body of green mussels. Several areas of cultivation and capture of mussels in Indonesia are located around industries and human activities that can produce pollutants. This is a danger signal for green mussel consumers because of the accumulation of heavy metals. 
Asian green mussel is a food that is quite popular with the community but can endanger public health due to the accumulation of heavy metals. Therefore, we examine the concentration of heavy metals in green mussel tissue in the coastal areas, particularly the island of Java, Indonesia. This study aims to provide an overview of the ability of green mussels as a seawater bioindicator and the health risks associated with consuming green mussels that have been contaminated with heavy metals.

\section{Methods}

Data were collected through PubMed and Google Scholar with the keywords green mussel, sea pollution, and Indonesia. A total of 4 articles were obtained from PubMed and 263 articles from Google Scholar. A total of 7 full-text articles assessed for eligibility. The article was investigated regarding the concentration of $\mathrm{Pb}, \mathrm{Hg}$, and $\mathrm{Cd}$ in the green mussel tissue. Most of the sampling locations for green mussels are on the north coast of Java Island.

Based on the studies that have been carried out in the article, there are 12 sampling locations for green mussels. The sampling locations consisted of Bandar Lampung, Banten, Jakarta, Cirebon, Brebes, Semarang, Demak, Jepara, and Surabaya. There are locations whose samples were taken as many as two points, namely Jakarta, Cirebon, and Semarang. The location of the green mussel sample can be seen in Figure 1.

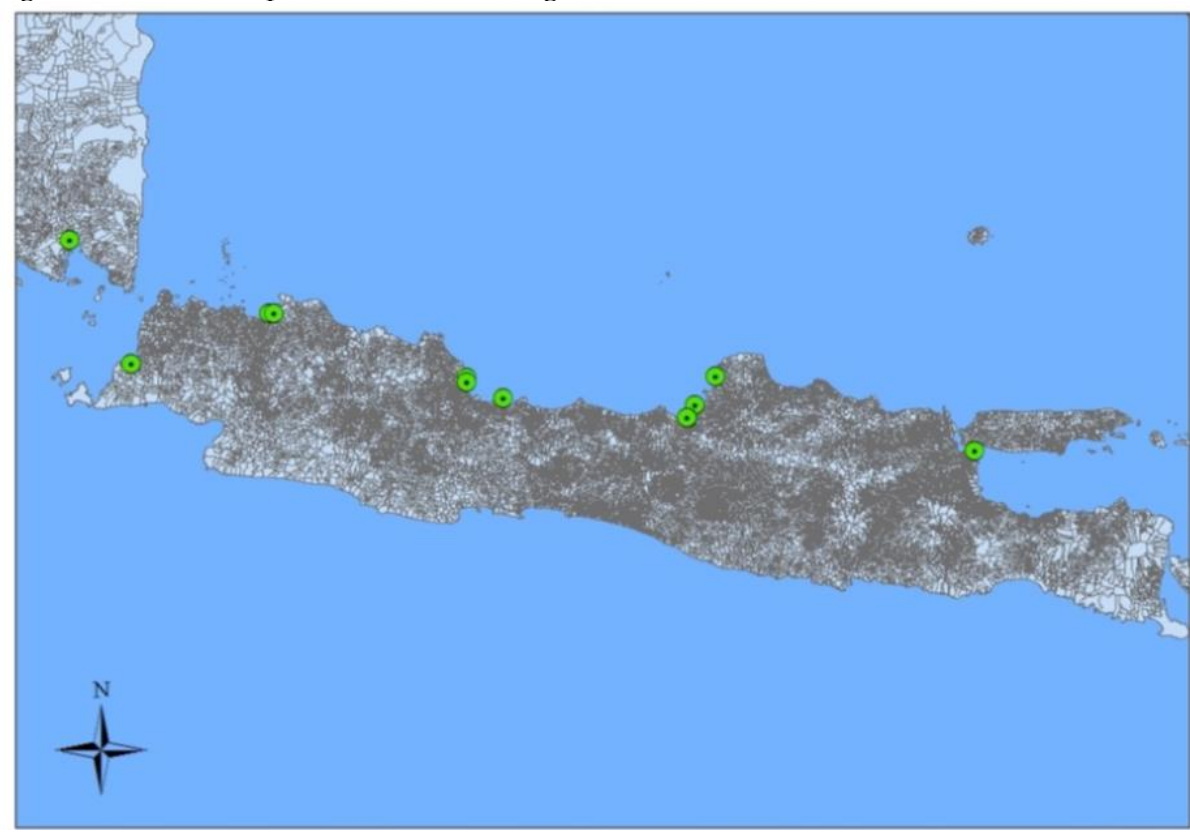

Figure 1. Green mussels sampling place.

\section{Green mussel as $\mathrm{Pb}, \mathrm{Hg}$, and $\mathrm{Cd}$ bioindicator}

Based on the studies that have been carried out, the concentrations of $\mathrm{Pb}, \mathrm{Hg}$, and $\mathrm{Cd}$ in the green mussel tissue from the sampling location are as follows:

Table 1. The concentration of $\mathrm{Pb}, \mathrm{Hg}$ and $\mathrm{Cd}$ in green mussel tissue in Indonesia.

\begin{tabular}{|c|c|c|c|c|c|}
\hline \multirow[t]{2}{*}{ No. } & \multirow[t]{2}{*}{ Green mussels sampling place } & \multicolumn{3}{|c|}{ Concentration (mg/kg) } & \multirow{2}{*}{$\begin{array}{c}\text { Author and year of } \\
\text { publication }\end{array}$} \\
\hline & & $\mathbf{P b}$ & $\mathrm{Hg}$ & $\mathrm{Cd}$ & \\
\hline 1 & Karangreja Village, Cirebon & 2,66 & 0,01 & 0,73 & Andayani, 2020 [16] \\
\hline 2 & Karangdempel Village, Brebes & 3,52 & 0,01 & 0,4 & \\
\hline 3 & Kali Baru, Jakarta & 29,4 & 11,7 & 0,42 & \\
\hline 4 & Panimbangjaya Village, Banten & 0 & 0 & 0,068 & \\
\hline 5 & Bondet waters, Cirebon & 4,99 & 0,03 & 0,87 & Nurhayati, 2019 [17] \\
\hline 6 & Industrial zone, Jakarta & 6.77 & 6.77 & - & Simbolon, 2018 [18] \\
\hline 7 & Industrial zone, Semarang & 0.603 & 0.603 & 0.0215 & Yulianto, 2020 [19] \\
\hline 8 & Semarang Harbor & - & - & 0.0311 & \\
\hline 9 & Jepara & 1,27 & 1,27 & 0,95 & Yulianto, 2019 [20] \\
\hline 10 & Surabaya & - & 0.26 & - & Suryono, 2019 [21] \\
\hline 11 & Demak & - & 0.09 & - & \\
\hline 12 & Pasaran island, Bandar Lampung & - & - & 0.0316 & Maharani, 2019 [22] \\
\hline
\end{tabular}


Saleh et al. I The use of green mussel as bioindicator

Based on the regulation of Indonesia food and drug administration number 5 of 2018, the maximum acceptable limit for $\mathrm{Pb}$ in green mussel tissue is $0.2 \mathrm{mg} / \mathrm{kg}$ [23]. Table 1 shows that the location for the sampling of green mussels that meet the requirements is Panimbangjaya Village. Pb concentration in the tissue's Panimbangjaya Village was not detected. The highest $\mathrm{Pb}$ concentration in green mussel is found in Kali Baru and the industrial zone, Jakarta.

The concentration of $\mathrm{Hg}$ in green mussel tissue from several samples is still categorized as safe because it has not exceeded the maximum acceptable limit set by the food and drug administration of the Republic of Indonesia. The maximum acceptable limit for $\mathrm{Hg}$ in tissue is $0.5 \mathrm{mg} / \mathrm{kg}$ according to the standards of the food and drug administration of the Republic of Indonesia [23]. The Hg concentration that exceeds the standard in Kali Baru, Jakarta is $11.7 \mathrm{mg} / \mathrm{kg}$.

The maximum acceptable limit on $\mathrm{Cd}$ in green mussel tissue is $0.1 \mathrm{mg} / \mathrm{kg}$ according to the regulations of the food and drug administration of the Republic of Indonesia [23]. Four sampling locations showed that the concentration of Cd in green mussel exceeded the maximum acceptable limit. The four sampling locations were Karangreja Village (Cirebon), Kali Baru (Jakarta). Bondet (Cirebon) and Jepara. Sources of pollution in the waters of Bondet, Cirebon, come from the industrial, market, and domestic waste [24]. Industrial waste is a source of pollution in Kali Baru (Jakarta) and Karangreja (Cirebon) [16]. The pollution in the waters of Jepara is influenced by industrial and domestic waste [20].

Green mussels are included in the bivalve group which is filter feeders in the water. All types of pollutants can be absorbed by shellfish so that they become bioindicators of water quality $[25,26]$. The pollutant that is absorbed by shellfish so that it accumulates in its body is called bioaccumulation. Various water pollutants can accumulate in the mussel. Even certain types of parasites can accumulate in shellfish so that they have the potential to be zoonotic if consumed by humans [27]. Heavy metals that are difficult to decompose in the waters cause these pollutants to accumulate in the body tissue [28]. The more anthropogenic pollutants that enter seawater, the greater their accumulation into the tissue. Human activities that produce waste in coastal areas can reduce the carrying capacity of the environment [29].

Scientists have recommended the use of shellfish as a bioindicator for decades. The nature of shellfish that remain in an ecosystem for a long time and have a low ability to metabolize pollutants in the waters makes it a bioindicator of water quality [30]. The use of shellfish as a bioindicator is better able to describe the quality of seawater in the past and present than using only sediment and water sample measurements. The level of accumulation of heavy metals in shellfish can be found in different waters [31]. Pollutant concentration factors and ecosystem conditions can influence it.

Which of the sediments, water, or shellfish are more capable of accumulating heavy metals in the sea? Several studies have shown that there is a difference between sediment, water, or shellfish in accumulating heavy metals. This is greatly influenced by the characteristics of pollutants and the condition of the aquatic ecosystem. Bivalvia can accumulate more heavy metals than sediment and water in Argentina's coastal area [32]. Other studies in Egypt and Indonesia showed that the concentrations of $\mathrm{Cd}, \mathrm{Cu}$, and $\mathrm{Zn}$ were higher in the seashell tissue compared to sediments [10,33]. However, in contrast to the results of the study in Turkey, it showed that the concentrations of $\mathrm{Cd}, \mathrm{Cu}$, and $\mathrm{Zn}$ were higher in sediments than in other samples [34]. So it is difficult to conclude which of the three is better able to accumulate more metal. However, shellfish are more representative of long-term metal accumulation so they are used for seawater monitoring [35].

Some experts have explained that the examination of heavy metals in specific organs or tissues in shellfish is called a biomarker [36,37]. The organs that are used as biomarkers are the target tissue for accumulating heavy metals around it. The digestive glands can accumulate heavy metals so that they can be used as biomarkers [38]. Each aquatic biota has a different target tissue to be used as a biomarker. Green mussels are used as bioindicators to monitor heavy metal concentrations in seawater in several Southeast Asian countries especially Indonesia and Malaysia [38-42].

European countries also use shellfish as a bioindicator. cadmium concentration in shellfish in Gemlik Bay, Turkey, shows a value that exceeds the threshold required for consumption. The highest concentrations of heavy metals are found around industry and resorts around the bay of Gemlik [43]. Mining activities in coastal areas affect heavy metal contamination of shellfish. Mining activities in the Black Sea affect the $\mathrm{Cu}$ concentration in the tissue as required by the Turkish government [44]. Most of the shellfish found in coastal areas of Algeria is still safe from heavy metal accumulation [45]. Human activities in coastal areas have an influence on seawater quality and heavy metal contamination in these ecosystems.

\section{Bioaccumulation of heavy metal and health risk}

Green mussel is one of the most popular seafood in the world. However, there are health risks that can arise from consuming it. Bioaccumulation of heavy metal contamination in tissues can affect human health. Green mussels that have been exposed to heavy metals can present a carcinogenic and non-carcinogenic risk [46]. In assessing the amount of health risk caused by consuming green mussels that have been contaminated with heavy metals, Target Hazard Quotients (THQ) can be calculated. Several studies have shown that the concentration of heavy metals in tissues concerning THQ is still safe for human health. THQ measurement on the consumption of green mussel originating from Jakarta Bay shows the category safe for consumption [2]. THQ measurements in Algeria and Turkey also show the health risks posed by consuming shellfish are still safe for health $[45,47]$. 


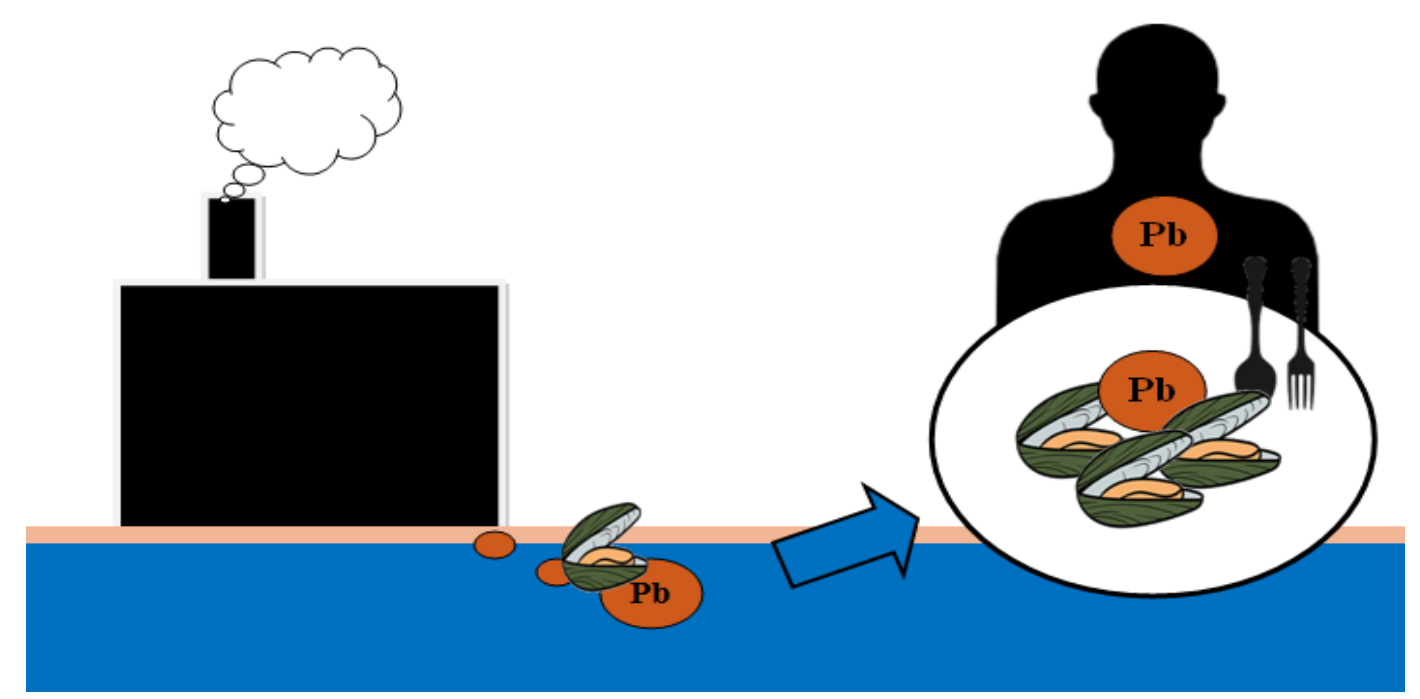

Figure 2. The mechanism of the entry of heavy metals into the human body through green mussels

Based on Figure 2, the entry of heavy metals into the food chain affects human health because humans are consumers of seafood. For example, green mussels exposed to heavy metals will accumulate in their bodies [48]. Heavy metals pollute the aquatic environment can enter green mussels tissues so that which is harmful to health if consumed by humans [22]. The green mussel intestine is the organ of the body that accumulates heavy metals [49]. Should not consume shellfish taken around the industry because it is susceptible to heavy metal contamination.

Prevention of exposure to heavy metals due to the consumption of shellfish must be a priority for governments in various countries. Efforts to prevent heavy metal contamination of shellfish must be started from the place where shells are raised. The location cultivation must be ensured that it is safe from exposure to heavy metals from anthropogenic activities around it [50]. This must be done to ensure public health, especially for those who enjoy seafood such as green mussels. The amount of shellfish consumption does not only occur in Southeast Asia but people in countries in the European continent also frequently consume it. The levels of heavy metal accumulation in Europe's shellfish consumption have varying concentrations. However, the clam samples and THQ still showed a safe for health as shown in Italy [51]. Consumption of larger portions of shellfish for a longer period of time can increase the health risk due to exposure to heavy metals from the shellfish consumed.

The location of cultivation will determine the health risks of consuming green mussels. consuming shellfish at the sampling sites. Especially if you consume a larger portion of shellfish because it has been contaminated with $\mathrm{Cd}$ and $\mathrm{Pb}$ [52]. Heavy metal concentrations that accumulate in green mussel are influenced by the environmental conditions [53]. Therefore, ensuring environmental health at the cultivation location determines the level of heavy metal concentrations in shellfish. The amount of carcinogenic risk due to consuming shellfish is greatly influenced by daily intake. People are advised to consume shellfish no more than one serving a week to reduce daily intake [54]. It is recommended that the consumed green mussel come from cultivation locations or other coastal areas far from industrial areas and other anthropogenic activities.

\section{Conclusions}

Consumption of green mussels can increase the health risk if you often consume green mussels from breeding or harvesting locations that have been contaminated with heavy metals. Environmental quality monitoring efforts around the cultivation and catching of green mussels must be carried out routinely by the local government.

\section{Conflict of interest}

The authors declare that there is no conflict of interest in this article

\section{CRediT author statement}

IS: Conceptualization, Methodology; S: Data curation, Writing- Original draft preparation, VP: Writing - Review \& Editing; H: Supervision, Validation

\section{ORCID}

Syamsir: 0000-0001-5228-6758

Vita Pramaningsih: 0000-0001-8104-0618 
Saleh et al. I The use of green mussel as bioindicator

\section{References}

[1] Indonesian Ministry of Trade. Analysis of Food Consumption Dynamics on Indonesian Society. Jakarta; 2013. http://bppp.kemendag.go.id/media_content/2017/08/LAPORAN_DINAMIKA_POLA_KONSUMSI.pdf

[2] Putri AK, Barokah GR, Andarwulan N. Human health risk assessment of heavy metals bioaccumulation in fish and mussels from Jakarta Bay. Squalen Bull Mar Fish Postharvest Biotechnol 2017;12(2):75-83 http://dx.doi.org/10.15578/squalen.v12i2.286

[3] Oktavilia S, Prayogi R, Abdulah R. Indonesian fish consumption : an analysis of dynamic panel regression model. In IOP Conf Ser Earth Environ Sci 2019;246(1):012005. https://doi.org/10.1088/1755-1315/246/1/012005

[4] Noor NM, Nursyam H, Widodo MS, Risjani Y. Biological aspects of green mussels perna viridis cultivated on raft culture in pasaran coastal waters , Indonesia. AACL Bioflux 2019;12(2):448-56.

[5] Cebu EH. Profile of green mussel farmers in samar philippines. J Acad Res 2018;3(1):11-9.

[6] Soon TK, Ransangan J. Feasibility of green mussel, perna viridis farming in Marudu Bay, Malaysia. Aquac Reports 2016;4:130-5. http://dx.doi.org/10.1016/j.aqrep.2016.06.006

[7] Srisuphanunt M, Saksirisampant W, Karanis P. Detection of cryptosporidium oocysts in green mussels (perna viridis) from shell-fish markets of Thailand. Parasite 2009;16(3):235-239. http://dx.doi.org/10.1051/parasite/2009163235

[8] Sagita A, Kurnia R, Sulistiono. Strategy of utilization coastal waters for green mussel (perna viridis L .) culture in Kuala Langsa , Aceh Province. J Ilmu Pertan Indones. 2017;22(3):172-179. http://doi.org/10.18343/jipi.22.3.172

[9] Wicaksono A, Lazuardi W, Astuti AP, Maitela T, Estigade AP, Aziz MH, et al. Coastal water environment suitability studies for green mussel cultivation in pasaran island, lampung bay. In Sixth Geoinformation Science Symposium 2019;11311:113110D. https://doi.org/10.1117/12.2548485

[10] Yona D, Sartimbul A, Rahman MA, Sari SHJ, Mondal P, Hamid A, et al. Bioaccumulation and health risk assessments of heavy metals in mussels collected from madura strait, Indonesia. J Ilm Perikan dan Kelautan 2021;13(1):20-28. http://dx.doi.org/10.20473/jipk.v13i1.24677

[11] Barokah GR, Dwiyitno D, Nugroho I. Heavy metals contamination ( $\mathrm{Hg}$, $\mathrm{Pb}$ and $\mathrm{Cd}$ ) dan batas aman konsumsi kerang hijau (perna virdis) dari perairan teluk jakarta di musim penghujan. Pascapanen Dan Bioteknologi 2019;14(2). http://dx.doi.org/10.15578/jpbkp.v14i2.611

[12] Kamaruzzaman BY, Ong MC, Zaleha K, Shahbudin S. Levels of heavy metals in green-lipped mussel perna veridis (Linnaeus) from muar estuary, Johore, Malaysia. Pakistan J Biol Sci 2008;11(18):2249-2253. https://doi.org/10.3923/pjbs.2008.2249.2253

[13] Bayen S, Thomas GO, Lee HK, Obbard JP. Organochlorine pesticides and heavy metals in green mussel, perna viridis in Singapore. Water Air Soil Pollut 2004;155(1):103-116. https://doi.org/10.1023/B:WATE.0000026524.99553.55

[14] Whyte AL, Hook GR, Greening GE, Gibbs-Smith E, Gardner JP. Human dietary exposure to heavy metals via the consumption of greenshell mussels (Perna canaliculus Gmelin 1791) from the Bay of Islands, northern New Zealand. Sci Total Environ 2009;407(14):4348-4355. https://doi.org/10.1016/j.scitotenv.2009.04.011

[15] Buddo DSA, Steele RD, Webber MK. Public health risks posed by the invasive Indo-Pacific green mussel, perna viridis (Linnaeus, 1758 ) in Kingston Harbour, Jamaica. BioInvasions Rec 2012;1(3):171-178.

http://dx.doi.org/10.3391/bir.2012.1.3.03

[16] Andayani A, Koesharyani I, Fayumi U, Rasidi R, Sugama K. Akumulasi logam berat pada kerang hijau di perairan pesisir jawa. oseanologi dan limnol di Indones 2020;5(2). https://doi.org/10.14203/oldi.2020.v5i2.279

[17] Nurhayati D, Putri DA. Bioakumulasi logam berat pada kerang hijau (perna viridis) di perairan cirebon beradasarkan musim yang berbeda. J Akuatika Indones 2019;4(1):6-10. https://doi.org/10.24198/jaki.v4i1.23484

[18] Simbolon AR. Analisis risiko kesehatan pencemaran timbal $(\mathrm{Pb})$ pada kerang hijau (perna viridis) di perairan cilincing pesisir DKI jakarta. Oseanologi dan Limnol di Indones 2018;3(3):197-208. https://doi.org/10.14203/oldi.2018.v3i3.207

[19] Yulianto B, Radjasa OK, Soegianto A. Heavy metals ( $\mathrm{cd}, \mathrm{pb}, \mathrm{cu}, \mathrm{zn}$ ) in green mussel (perna viridis) and health risk analysis on residents of semarang coastal waters, central Java, Indonesia. Asian J Water, Environ Pollut 2020;17(3):71-76. https://doi.org/10.3233/AJW200039 
[20] Yulianto B, Oetari PS, Februhardi S, Putranto TWC, Soegianto A. Heavy metals (cd, pb, cu, zn) concentrations in edible bivalves harvested from northern coast of central Java, Indonesia. In: IOP Conference Series: Earth and Environmental Science 2019;259(1):012005. https://doi.org/10.1088/1755-1315/259/1/012005

[21] Suryono CA, Sabdono A, Subagiyo S. Bioakumulasi arsen (As) dan merkuri (Hg) pada bivalvia dari pesisir sekitar demak dan surabaya Indonesia. J Kelaut Trop 2019;22(2):157-164. https://doi.org/10.14710/jkt.v22i2.6257

[22] Maharani HW, Nurulita N, Yulianto H, Efendi E, Delis PC. Bioconcentration of cadmium heavy metal (Cd) on green mussle perna viridis linn, 1758 cultivated in Pasaran island waters, Lampung, Indonesia. AQUASAINS 2019;7(2):685-696. http://dx.doi.org/10.23960/aqs.v7i2.p685-696

[23] Indonesian Food and Drug Supervisory Agency. Regulation of the drug and food supervisory agency number 5 of 2018 concerning maximum limit of heavy metal contamination in processed food. Jakarta: Indonesian Food and Drug Supervisory Agency; 2018.

https://standarpangan.pom.go.id/dokumen/peraturan/2018/0. salinan PerBPOM 5 Tahun 2018 Cemaran Logam Ber at join $4 . \mathrm{pdf}$

[24] Indonesia Institute of Sciences. Laporan akhir tahunan kegiatan penelitian tahunanggran 2017. http://oseanografi.lipi.go.id/laporan/DWI HINDARTI_Laporan akhir tahun 2017.pdf

[25] Chakraborty K, Chakkalakal SJ, Joseph D, Asokan PK, Vijayan KK. Nutritional and antioxidative attributes of green mussel (perna viridis L .) from the southwestern coast of India. J Aquat Food Prod Technol 2016;25(7):968-85. https://dx.doi.org/10.1080/10498850.2015.1004498

[26] Nacua AE, Pascual ABM, Macer MCR. Assessment of heavy metals in Philippine green musselsp perna viridis and level of coliform on manila bay adjacent to the coastline of sipac almacen, Navotas Philippines. Int J Adv Eng Manag Sci 2019;5(5):319-26. https://dx.doi.org/10.22161/ijaems.5.5.4

[27] Oliveira GFM, do Couto MCM, de Freitas Lima M, do Bomfim TCB. Mussels (Perna perna) as bioindicator of environmental contamination by cryptosporidium species with zoonotic potential. Int J Parasitol Parasites Wildl 2016;5:2833. https://doi.org/10.1016/j.ijppaw.2016.01.004

[28] Jović MD, Stanković A, Stanković-Beskoski Lj, Tomić I, Degetto S, Stanković S. Mussels as a bio-indicator of the environmental quality of the coastal water of the boka kotorska bay (Montenegro). J Serbian Chem Soc 2011;76(6):933-946. https://doi.org/10.2298/ISC101007075I

[29] Huhn M, Zamani N, Lenz M. A ferry line facilitates dispersal : Asian green mussels perna viridis ( Linnaeus , 1758 ) detected in eastern Indonesia. BioInvasions Rec 2015;4(1):23-29. http://dx.doi.org/10.3391/bir.2015.4.1.04

[30] Azizi G, Akodad M, Baghour M, Layachi M, Moumen A. The use of mytilus spp. mussels as bioindicators of heavy metal pollution in the coastal environment. A review. J Mater Environ Sci 2018;9(4)1170-1181.

https://doi.org/10.26872/jmes.2018.9.4.129

[31] Belabed BE, Laffray X, Dhib A, Fetouna-Belakhal M, Turki S, Aleya L. Factors contributing to heavy metal accumulation in sediments and in the intertidal mussel Perna perna in the Gulf of Annaba (Algeria). Mar Pollut Bull 2013;74(1):477-489 https://doi.org/10.1016/j.marpolbul.2013.06.004

[32] Buzzi NS, Marcovecchio JE. Heavy metal concentrations in sediments and in mussels from Argentinean coastal environments, South America. Environ Earth Sci 2018;77(8):1-13. https://doi.org/10.1007/s12665-018-7496-1

[33] Nour HE, El-Sorogy AS. Heavy metals contamination in seawater, sediments and seashells of the Gulf of Suez, Egypt. Environ Earth Sci 2020;79(27)1-12. https://doi.org/10.1007/s12665-020-08999-0

[34] Baltas H, Sirin M, Dalgic G, Bayrak EY, Akdeniz A. Assessment of metal concentrations ( $\mathrm{Cu}$, $\mathrm{Zn}$, and Pb ) in seawater, sediment and biota samples in the coastal area of Eastern Black Sea, Turkey. Mar Pollut Bull 2017;122(1-2):475-482. http://dx.doi.org/10.1016/j.marpolbul.2017.06.059

[35] Chakraborty S, Owen G. Metal distributions in seawater, sediment and marine benthic macroalgae from the South Australian coastline. Int J Environ Sci Technol 2014;11(5):1259-1270. https://doi.org/10.1007/s13762-013-0310-4

[36] Martínez-Gomez C, Robinson CD, Burgeot T, Gubbins M, Halldorsson HP, Albentosa M, et al. Biomarkers of general stress in mussels as common indicators for marine biomonitoring programmes in Europe : The ICON experience. Mar Environ Res 2017;124:70-80. http://dx.doi.org/10.1016/j.marenvres.2015.10.012

[37] Chen CY, Lu TH, Yang YF, Liao CM. Marine mussel-based biomarkers as risk indicators to assess oceanic regionspecific microplastics impact potential. Ecol Indic 2021;120:106915. https://doi.org/10.1016/j.ecolind.2020.106915 
Saleh et al. I The use of green mussel as bioindicator

[38] Giarratano E, Duarte CA, Amin OA. Biomarkers and heavy metal bioaccumulation in mussels transplanted to coastal waters of the beagle channel. Ecotoxicol Environ Saf 2010;73(3):270-279. https://doi.org/10.1016/j.ecoenv.2009.10.009

[39] Chandurvelan R, Marsden ID, Gaw S, Glover CN. Biochemical biomarker responses of green-lipped mussel, Perna canaliculus, to acute and subchronic waterborne cadmium toxicity. Aquat Toxicol 2013;140-141:303-313. http://dx.doi.org/10.1016/j.aquatox.2013.06.015

[40] Putri LSE, Prasetyo AD, Arifin Z. Green mussel (perna viridis 1.) As bioindicator of heavy metals pollution at kamal estuary, Jakarta bay, Indonesia. J Environ Res Dev 2012;6(3):389-396.

[41] Yap CK, Ismail A, Tan SG. Heavy metal (Cd, Cu, Pb and $\mathrm{Zn}$ ) concentrations in the green-lipped mussel perna viridis (Linnaeus) collected from some wild and aquacultural sites in the west coast of Peninsular Malaysia. Food Chem 2003;84(4):569-575. https://doi.org/10.1016/S0308-8146(03)00280-2

[42] Harsono NDBD, Ransangan J, Denil DJ, Tan KS. Heavy metals in marsh clam (Polymesoda expansa) and green mussel (perna viridis) along the northwest coast of Sabah, Malaysia. Borneo J Mar Sci Aquac. 2017;1:25-32. https://doi.org/10.51200/bjomsa.v1i0.987

[43] Ünlü S, Topçuoğlu S, Alpar B, Kırbaşoğlu Ç, Yılmaz YZ. Heavy metal pollution in surface sediment and mussel samples in the Gulf of Gemlik. Environ Monit Assess 2008;144(1):169-178. https://doi.org/10.1007/s10661-007-9986-6

[44] Cevik UĞUR, Damla N, Kobya AI, Bulut VN, Duran CELAL, Dalg1c G, et al. Assessment of metal element concentrations in mussel (M. Galloprovincialis) in Eastern Black Sea, Turkey. J Hazard Materials 2008;160(2-3):396-401. https://doi.org/10.1016/j.jhazmat.2008.03.010

[45] Guendouzi Y, Soualili DL, Fowler SW, Boulahdid M. Environmental and human health risk assessment of trace metals in the mussel ecosystem from the Southwestern Mediterranean. Mar Pollut Bull 2020;151:110820. https://doi.org/10.1016/j.marpolbul.2019.110820

[46] Yuan Y, Sun T, Wang H, Liu Y, Pan Y, Xie Y, et al. Bioaccumulation and health risk assessment of heavy metals to bivalve species in Daya bay (South China Sea): consumption advisory. Mar Pollut Bull 2019;150:110717. https://doi.org/10.1016/j.marpolbul.2019.110717

[47] Alkan N, Alkan A, Demirak A, Bahloul M. Metals/metalloid in marine sediments, bioaccumulating in macroalgae and a mussel. Soil Sediment Contam 2020;29(5):569-594. https://doi.org/10.1080/15320383.2020.1751061

[48] Jaishankar M, Tseten T, Anbalagan N, Mathew BB, Beeregowda KN. Toxicity, mechanism and health effects of some heavy metals. Interdiscip Toxicol 2014;7(2):60-72. https://doi.org/10.2478/intox-2014-0009

[49] WWF Indonesia. Shellfish Fishing. Jakarta: WWF Indonesia; 2015. p. 14. http://awsassets.wwf.or.id/downloads/capture bmp kerang des 2015.pdf

[50] Benniona M, Morrison L, Brophy D, Carlsson J, Abrahantes JC, Graham CT. Trace element fingerprinting of blue mussel (Mytilus edulis) shellsand soft tissues successfully reveals harvesting locations. Sci Total Environ 2019;685:50-58. https://doi.org/10.1016/j.scitotenv.2019.05.233

[51] Chiesa LM, Ceriani F, Caligara M, Di Candia D, Malandra R, Panseri S, et al. Mussels and clams from the italianfish market. is there a human exposition risk to metals and arsenic? Chemosphere 2018;194:644-649.

https://doi.org/10.1016/j.chemosphere.2017.12.041

[52] Gedik K. Bioaccessibility of $\mathrm{Cd}, \mathrm{Cr}, \mathrm{Cu}, \mathrm{Mn}, \mathrm{Ni}, \mathrm{Pb}$, and $\mathrm{Zn}$ in mediterranean mussel (mytilus galloprovincialis lamarck, 1819) along the southeastern Black Sea coast. Hum Ecol Risk Assess 2017;24(3):754-766. https://doi.org/10.1080/10807039.2017.1398632

[53] Kumar V, Sinha AK, Rodrigues PP, Mubiana VK, Blust R, De Boeck G. Linking environmental heavy metal concentrations and salinity gradients with metal accumulation and their effects: A case study in 3 mussel species of Vitória estuary and Espírito Santo bay, Southeast Brazil. Sci Total Environ 2015;523:1-15. https://doi.org/10.1016/j.scitotenv.2015.03.139

[54] Bat L, Arici E, Öztekin A. Human health risk assessment of heavy metals in the Black Sea: Evaluating mussels. Curr World Environ 2018;13(1):15. https://doi.org/10.12944/CWE.13.1.03 